UDK 595.42:582.685.4(497.6 Sarajevo)

\title{
MITES ON LINDEN TREES (TILIA SPP.) IN SARAJEVO
}

Grinje lipa (Tilia spp.) u Sarajevu

Kemala Doljančić ${ }^{1}$, Mirza Dautbašić ${ }^{1}$, Osman Mujezinović ${ }^{1}$

\begin{abstract}
Urban green areas in Sarajevo are of the most importance for the overall appearance of the city and the quality of life in it. In recent years there has been a decline in the area under vegetation. The main reason for the loss and degradation of green areas is anthropogenic factor which predisposes urban greenery with its activities to various other biotic and abiotic factors. Air pollution, drought, high temperatures, soil and water pollution are group of abiotic factors which synergetic cause physiological changes in plant species. The fall of physiological resistance causes exposure of plants to biotic factors, especially insects, fungi, and recently mites.

In this paper, the research was conducted in order to determine the identification of harmful species of mites on the linden trees and determine the intensity of infection. Linden trees are designed as an avenue that stretches from Suada and Olga Bridge to the TV home in Alipašino Polje. Identification was based on symptoms established on the leaf material directly in the field and in the laboratory with the use of microscopes and binoculars. Laboratory studies were carried out at the Faculty of Forestry in Sarajevo. The intensity of infection of trees was determined HAWKSWORH'S six class system (1986).

A total of 200 trees were analyzed of which is the 136 infected by phytophagous mites. We identified five types of mites. Found species belonged to the family Eriophyidae and Tetranychidae. Following types of mites are identified from the first family: Eriophyestiliae (Eriophyoidea), Eriophyestiliaelateannulatus (Eriophyoidea), Eriophyesexilis (Eriophyoidea), and Eriophyesleiosoma (Eriophyoidea). From other family revealed the presence of mite Eotetranychustiliarum (Tetranychoidea).

The result of research conducted in the period from May to August showed a tendency of all recorded species of mites to the lower parts of the tree crown and going to the higher parts their numbers are decreasing.
\end{abstract}

Key words: urban environment, urban green areas, linden, phytophagous mites

\footnotetext{
${ }^{1}$ Faculty of Forestry, University of Sarajevo
} 


\section{INTRODUCTION - Uvod}

The urban environment is a dynamic process, which constantly expands and upgrades. With constant development of technology the number of buildings that cause greater congestion with the gray areas increases. This raising of cities reduced quality of life and makes it stressful and difficult. Due to these, emphasis is placed on the concept of a sustainable city, which seeks to emphasize the importance and the significance of urban green areas. Sustainable city is actually maintaining and increasing riches of the environment (ŠIMUNOVIĆ, 2007).

Urban green spaces are public spaces located in urban areas, which are mostly covered with vegetation and used directly for active and passive recreation, or indirectly through the benefits they have for the urban environment, which are available to the citizens and serve the different needs of citizens, which are enhancing quality of life in urban areas (ČOMIĆ et al, 2009).Urban green spaces are important elements of each city. They are part of the image of the city, extending ecological diversity and the essential, structural and functional elements that make cities and urban regions more suitable for housing (TIŠMA et al). The role of plants in urban areas is multiple. The positive role of plants is not only reflected in the decorative-aesthetic role, but also a number of other functions, the most important are sanitary-hygienic and cultural and educational (LJUJIĆ-MIJATOVIĆ AND MRDOVIĆ, 1998).

Linden (Tilia spp.) is one of the commonly used species in urban areas. It is well adapted to urban conditions, and is used to raise parks, avenue, alley, etc. Although lime is considered adaptable species to changing environmental conditions, it is daily exposed to many negative factors, which depending on the manner and intensity of action can cause more or less significant damage to trees.

In recent years, the mites are becoming a very important issue forconsideration. The problem of harmful species of mites emerged from after World War II and is a direct consequence of the so-called. "Green revolution" that is disrupting natural ecosystems, undue arrogance and ignoring the laws of nature, so that they are considered "example of pests produced by man" (PETANOVIĆ, 2004).

Mites belong to the subclass Acarina. Most of the harmful species is widespread, but some are economically more important than the other and exhibit different harmful effects depending on the characteristics of agro ecosystems in different climates, in terms of plant species grown in the open field (PETANOVIĆ et al, 2010).

The success of this group in populating very diverse habitats is in correlation with the small size of the body (an average of 250 to 750 microns) and the possibility of exploitation of microhabitats (PETANOVIĆ, 2004). The main modes of transmission are through the wind mites (anemochory), animals and anthropogenic influence which are considered as the most important and the most common means of transmission. 
From phytomedical point of view the most important pest species from families red spiders - Tetranychidae, Bryobiidae, flat mites - Tenuipalpidae, soft skinned mites -Tarsonemidae, gall mites - Eriophyidaeand roots mites Tyroglyphidae, and useful species of predatory carnivorous mites from the family Phvtoseiidae (MACELJSKI et al, 2002).

Harmfulness of mites is manifested in an interval of less significant changes for the host plant to serious change for the health status of individuals. Depending on the types of mites, changes in plants can manifest itself through various forms of abnormalities on the surface of plant parts (galls, blisters, patches of irregular shapes, bulges, etc.) to necrosis and premature fall of the leaves-thus shortening the lifespan of individuals. Depending on the extent of the damage caused aesthetic function of plants in urban areas has been disturbed or degraded.

\section{MATERIAL AND RESEARCH METODS - Materijal i metode istraživanja}

Research was carried out on lime avenue in Sarajevo. Research facility is divided into three parts. It is located at an altitude of $509-535 \mathrm{~m}$ and extends from east to west.

200 trees were randomly selected on which the analysis was conducted involving the determination and identification of plant-eating species of mites and determining the intensity of infection on trees.

The determination of these pests was carried out directly on the site according to the infected symptoms on the leaf material. In the event that the same could not be executed immediately on the site, it was carried out in the laboratories of the Department of forest protection and urban greenery, the Faculty of Forestry in Sarajevo. For the determination of mites were used keys of known authors HARTMANN et al (2007); BUTIN et al (2008); MATOŠEVIĆ (2004); PETANOVIĆ (2004); MACELJSKI (2002) and others.

The intensity of infection of trees was determined HAWKSWORH'S six class system (1986) so that the tree crown segments into three equal parts. After that segmented portion of the canopy is evaluated according to the following scale:

- 0 - no symptoms of mite

- 1 - poor infection (less than half of the branches showed the presence of mites)

- 2 - severe infection (for more than half of the branches showed the presence of mites).

After determining the grade of the crown according to this scale, grades from all three segments of the crown are added, resulting in a total index for the analyzed tree infestations. The index can range from 0-6. Research was conducted in May, June, July and August 2015. 


\section{RESULTS - Rezultati}

The presence of plant-eating species of mites was confirmed at 136 linden trees of 200 taken for analysis. The results of processing the data collected along the avenue lime show the presence of 5 species of phytophagous mites. Found species belong to the families Eriophyidae and Tetranichydae. Eriophyes tiliae, Eriophyes tilia lateannulatus, Eriophyes exilis and Eriophyes leiosoma are mites from first mentioned family, while from other was identified mite Eotetranychus tiliarum.

\section{Eriophyes tiliae Nal.}

Eriophyes tiliae was found on the leaves of Tilia tomentosa and Tilia platyphyllos. Species identification was based on the galls formed on the leaf surface in May. Galls are initially green and maturing during July or August become reddish in color. Pricks are pointed tip length of $5-15 \mathrm{~mm}$. In some cases galls accrete at the base, while the peaks are separated. The interior of the galls is filled with hair and at the bottom there is a hole that used to go out to the surface of plant tissues. When there is an outbreak of mites, galls can sometimes cover the entire leaf area. Species does not lead to serious physiological changes in plants. It causes damage of an aesthetic nature which makes the tree loses its function in urban areas.

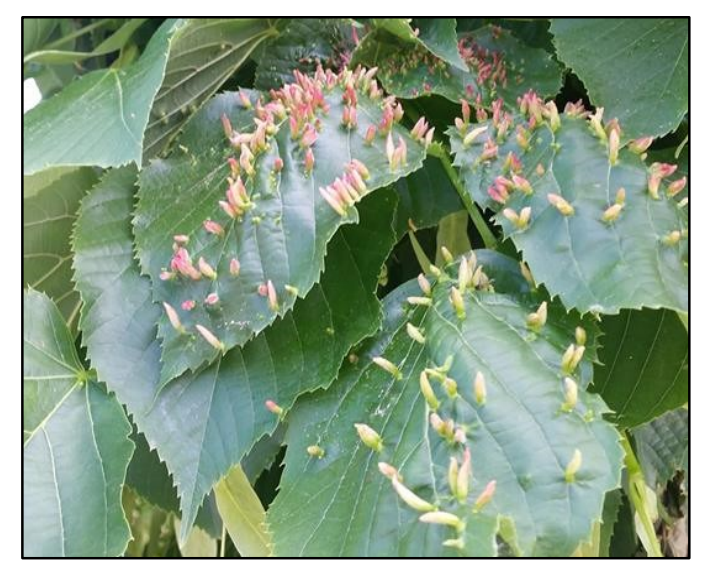

Figure 1.: Galls on silver linden leaf(Tilia tomentosa) caused by mite Eriophyes tiliae

Slika 1.: Gale na srebrnolisnoj lipi (Tilia tomentosa) uzrokovane grinjom Eriophyes tiliae

\section{Eriophyes tiliae lateannulatus Schulze.}

Mites cause the same symptoms as the previous species that may be observed in the spring. The difference compared with the previous type is that the length of the galls in this case is only $5 \mathrm{~mm}$. 


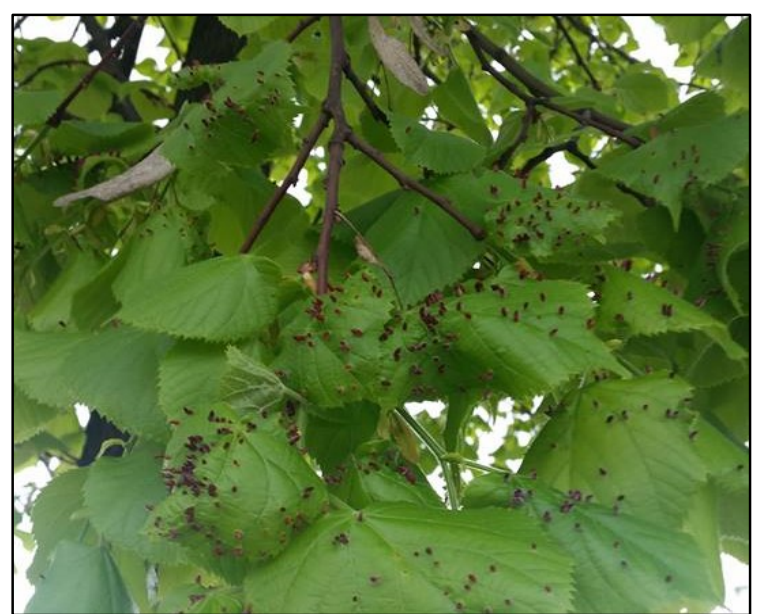

Figure 2.: Galls on leafs on large-leaved lime (Tilia platyphyllos)caused by mite Eriophyes tiliae lateannulatus

Slika 2.: Gale na listu velikolisne lipe (Tilia platyphyllos) uzrokovane grinjom Eriophyes tiliae lateannulatus

\section{Eriophyes exilis Nal.}

Eriophyes exilis on the leaf surface causes whitish-greenish spots without occurrence of distortion of the leaf surface. Freckles aging take on a brownish hue. On the reverse of leaf these places are off-white and hairy, irregular shape. Does not cause significant physiological changes in plant hosts. However, the effect of these mites is not negligible, because with theirs development plant loses its aesthetic role in landscape architecture.

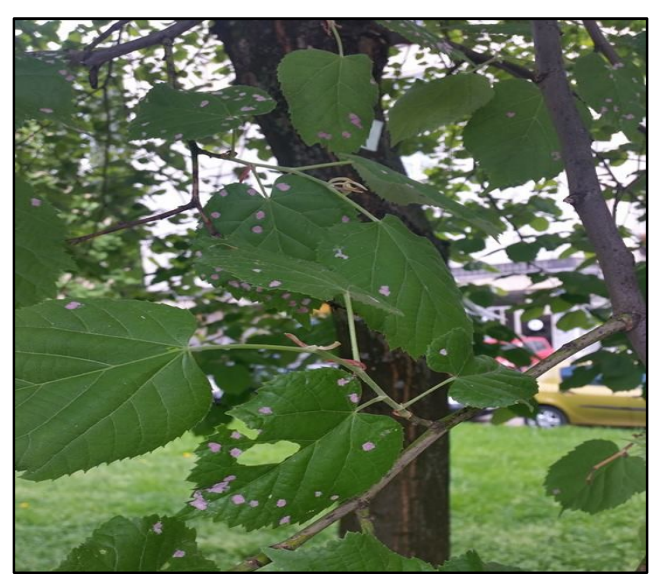

Figure 3.: White spots on surface of leaf caused by mite Eriophyes exilis Slika 3.: Bijele mrlje na površini lista uzrokovane grinjom Eriophyes exilis 


\section{Eriophyes leiosoma Nal.}

Mite causes the appearance of green bumps on the top of the leaf in May or June. They develop alongside of nerves. The bumps on the underside of the leaf are whitish and maturing they become brownish-red and tomentose. Species does not cause dangerous damage to the plant hosts, and even stronger attacks do not cause deformation of the leaf surface.

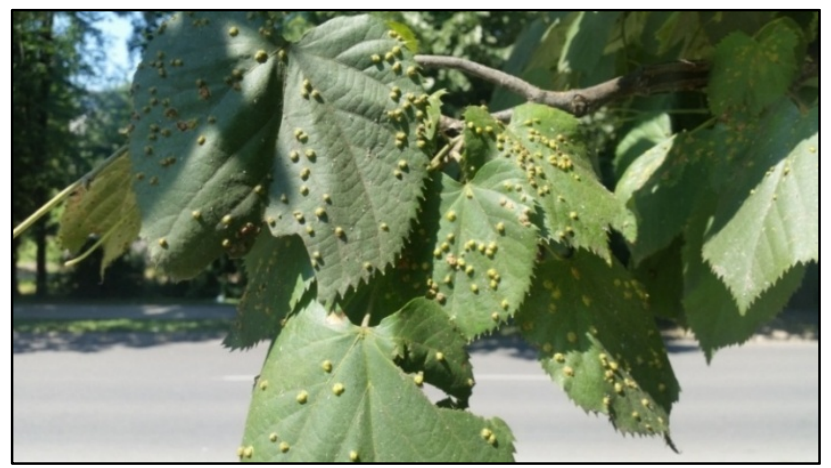

Figure 4.: Galls on silver linden leaf (Tilia tomentosa) caused by mite Eriophyes leiosoma Slika 4.: Gale na srebrnolisnoj lipi (Tilia tomentosa) uzrokovane grinjom Eriophyes leiosoma

\section{Eotetranychus tiliarum}

Eotetranychus tiliarum is one of the key lime pests. Eotetranychus tiliarum in favourable conditions causes high damage to the linden trees (SCHNEIDER et al, 2000). The attack is reflected in the discoloration of leaves extending from the bottom to the top of the crown, twisting the leafs from the back and causes its early falling off. Other species are important for the external appearance of the species. They lead to the creation of various types of abnormalities on the leaves like galls or other bulges. Because of the deformations linden loses aesthetic role in urban environments.

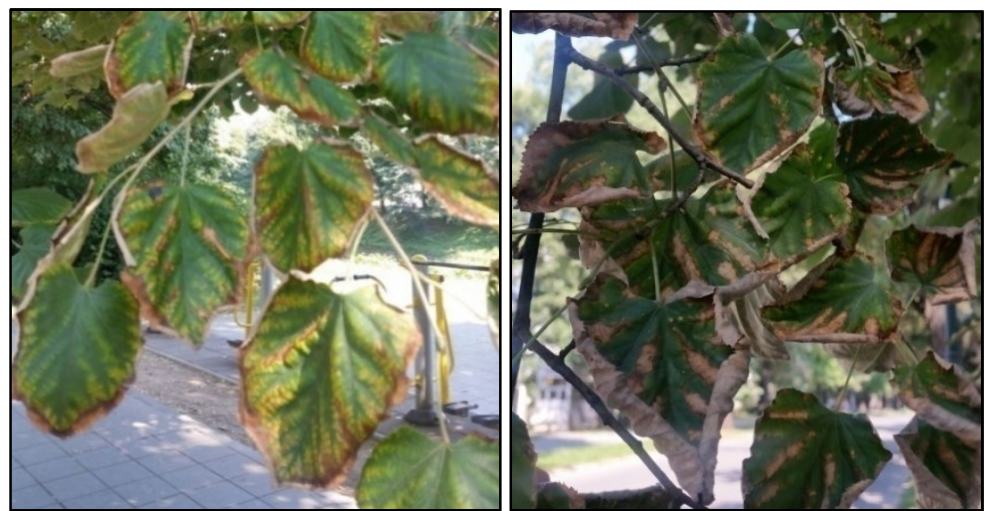

Figure 5 and 6.: Bronzing and twisting of linden leafs caused by attack of Eotetranychus tiliarum

Slike 5 i $6 .:$ Bronziranje i uvrtanje listova lipe uzrokovane napadom Eotetranychus tiliarum 
The distribution of the number of infected lime trees to the total index of infection is given in the graph 1 .

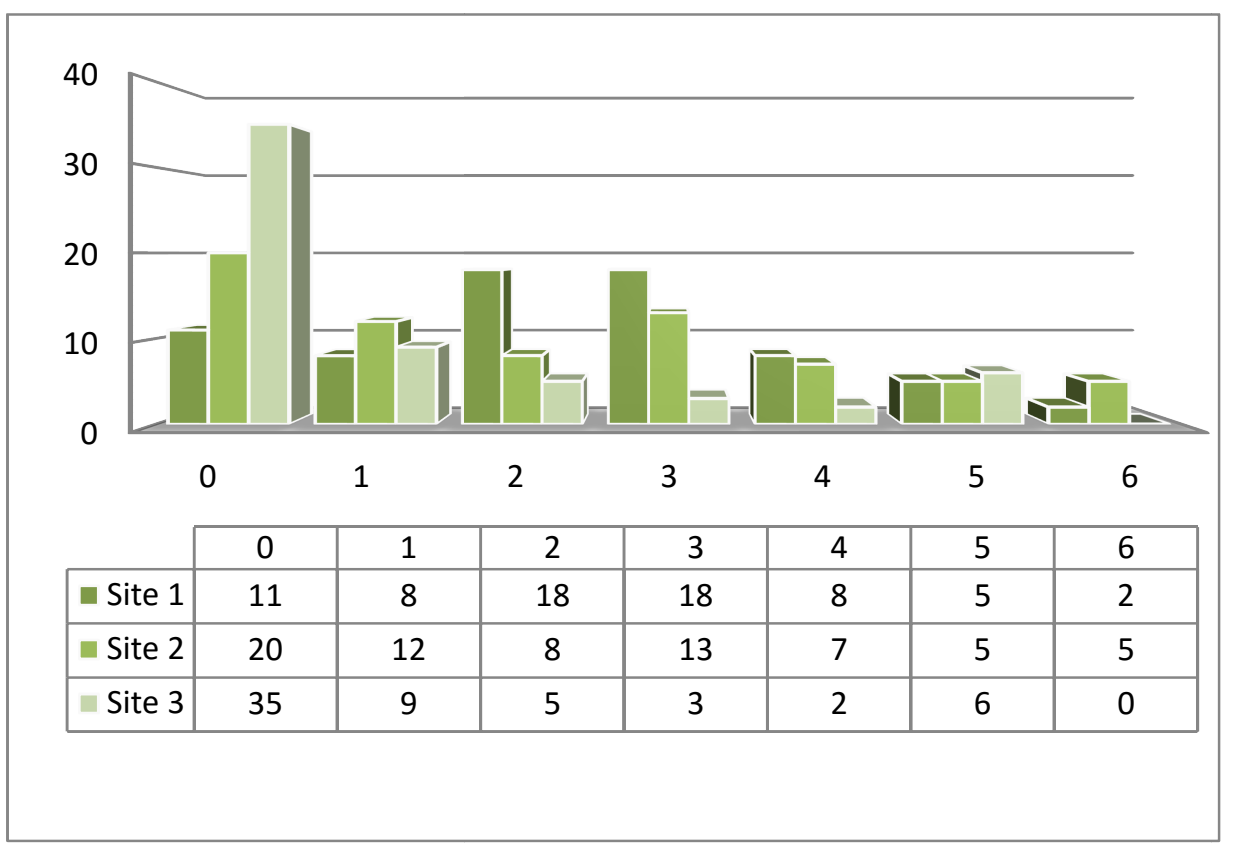

Graphic 1.: The overall index infestations by localities

Grafikon 1.: Sumarni prikaz infestacija po lokalitetima

The distribution of the number of infected lime trees according to the index of infection in the analyzed parts of the crown is given in Table 1 and Graph 2.

Table 1.: The overall index of infection in the analyzed parts of the canopy

Tabela 1.: Sumarni prikaz infestacije na analiziranim dijelovima krošnji

\begin{tabular}{|c|c|c|c|c|c|c|c|c|c|}
\hline & \multicolumn{3}{|c|}{$\begin{array}{c}\text { Bottom third of } \\
\text { crown }\end{array}$} & \multicolumn{3}{c|}{$\begin{array}{c}\text { Middle third of } \\
\text { crown }\end{array}$} & \multicolumn{4}{|c|}{$\begin{array}{c}\text { Top third of } \\
\text { crown }\end{array}$} \\
\hline Infestation index & 0 & 1 & 2 & 0 & 1 & 2 & 0 & 1 & 2 \\
\hline Site 1 & 11 & 25 & 34 & 27 & 33 & 10 & 51 & 17 & 2 \\
\hline Site 2 & 20 & 25 & 25 & 37 & 19 & 14 & 49 & 14 & 7 \\
\hline Site 3 & 35 & 10 & 15 & 47 & 5 & 8 & 54 & 6 & 0 \\
\hline Total: & 66 & 60 & 74 & 111 & 57 & 32 & 154 & 37 & 9 \\
\hline
\end{tabular}




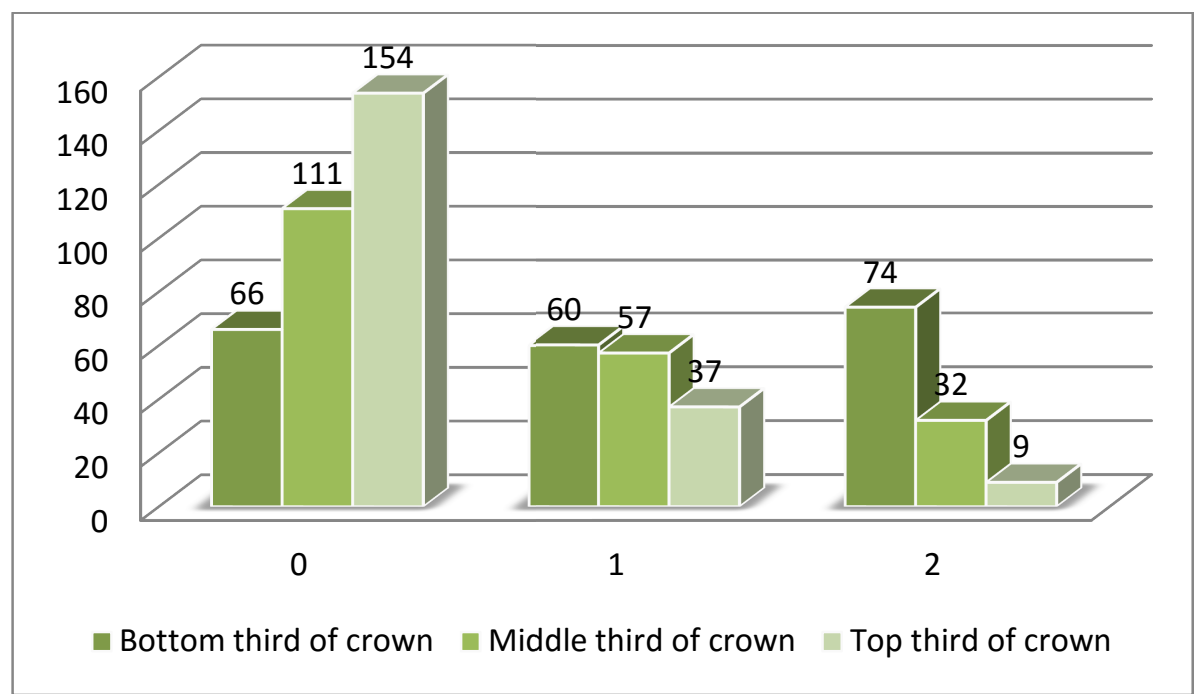

Graphic 2.: Distribution of infected lime trees according to the index of infection in the analyzed parts of the canopy

Grafikon 2.: Distribucija napadnutih stabala lipe prema indeksu infestacije u analiziranim dijelovima krošnji.

The statistical analysis of the studied parameters were carried out using OneWay ANOVA in statistical program Statgraphics Plus. The significance of differences between the individual categories of the tested parameter was determined using the Fisher LSD test. Results of statistical analysis of the impact of the site and the species of lime on the size of the average index of infection are given in Tables 2 and 3.

Table 2.: Influence of the site on the size of average index of infection of linden trees Tabela 2.: Uticaj lokaliteta na visinu prosječnog indeksa infestacije stabala lipe

\begin{tabular}{|l|c|c|c|c|c|}
\hline \multicolumn{1}{|c|}{ Source: Site } & Sum of Squares & Df & Mean square & F-Ratio & P - Value \\
\hline Between groups & 9,52381 & 2 & 4,7619 & 0,07 & 0.9349 \\
\hline Within groups & 1267,71 & 18 & 70,4286 & & \\
\hline Total: & 1277,24 & 20 & & & \\
\hline
\end{tabular}

Table 3.: Influence of the species of lime on the size of average index of infection of linden trees

Tabela 3.: Uticaj vrste lipe na visinu prosječnog indeksa infestacije stabala

\begin{tabular}{|l|c|c|c|c|c|}
\hline \multicolumn{1}{|c|}{ Source: } & & & & \\
Species of lime & Sum of Squares & Df & Mean Square & F- Ratio & P - Value \\
\hline Between groups & 423,525 & 2 & 211,762 & 1,64 & 0,2224 \\
\hline Within groups & 2329,71 & 18 & 129,429 & & \\
\hline Total & 2753,24 & 20 & & \\
\hline
\end{tabular}


Categories of analyzed parts of the tree crown to the number of infected leaves are shown in the tables 4 and 7 . The results of the impact of the exposure on the infected leaf foliage are provided in tables 5, 6, 8 and 9.

Table 4.: Categories of analyzed parts of the tree crown to the number of infected leaves Tabela 4.: Kategorije analiziranih dijelova krošnje prema broju infestiranih listova

\begin{tabular}{|l|c|c|c|c|c|}
\hline Categories & Count & Mean & Stnd. Error & $\begin{array}{c}\text { Lower } \\
\text { limit }\end{array}$ & $\begin{array}{c}\text { Upper } \\
\text { Limit }\end{array}$ \\
\hline East & 166 & 2,92771 & 0,25826 & 2,56979 & 3,28563 \\
\hline South & 163 & 2,73006 & 0,260625 & 2,36886 & 3,09126 \\
\hline North & 150 & 2,6 & 0,271685 & 2,22347 & 2,97653 \\
\hline West & 153 & 2,45098 & 0,269008 & 2,07816 & 2,8238 \\
\hline Total & 632 & 2,68354 & & & \\
\hline
\end{tabular}

Table 5.: The impact of exposure to infected foliage leaves

Tabela 5.: Uticaj izloženosti na infestaciju listova

\begin{tabular}{|lcc|ccc|}
\hline $\begin{array}{c}\text { Source: } \\
\text { Infection of leaves on } \\
\text { parts of crown }\end{array}$ & Sum of Squares & Df & Mean Square & $\begin{array}{c}\text { F- } \\
\text { Ratio }\end{array}$ & P- Value \\
\hline Between groups & 19,5713 & 3 & 6,52376 & 0,59 & 0,6222 \\
\hline Within groups & 6953,14 & 628 & 11,0719 & & \\
\hline Total & 6972,71 & 631 & & & \\
\hline
\end{tabular}

Table 6.: The significance of differences infestations main parts of the trees Tabela 6.: Značajnost razlika zaraženosti glavnih dijelova krošanja

\begin{tabular}{|c|c|c|}
\hline Compared categories & Difference of means & Lower/upper limit \\
\hline East-South & 0,197649 & 0,719134 \\
\hline East-North & 0,327711 & 0,734689 \\
\hline East-West & 0,47673 & 0,730895 \\
\hline South-North & 0,130061 & 0,737891 \\
\hline South-West & 0,279081 & 0,734114 \\
\hline North-West & 0,14902 & 0,749358 \\
\hline
\end{tabular}


Table 7.:Categories analyzed parts of the tree crown to the number of galls

Tabela 7.: Kategorije analiziranih dijelova krošnji prema broju gala

\begin{tabular}{|l|c|c|c|c|c|}
\hline Categories & Count & Mean & Stnd. error & Lower limit & $\begin{array}{c}\text { Upper } \\
\text { Limit }\end{array}$ \\
\hline East & 166 & 21,5181 & 3,31606 & 16,9223 & 26,1138 \\
\hline South & 164 & 18,3293 & 3,33622 & 13,7056 & 22,953 \\
\hline North & 151 & 19,0927 & 3,47686 & 14,2741 & 23,9113 \\
\hline West & 155 & 14,0323 & 3,43171 & 9,27623 & 18,7883 \\
\hline Total & 636 & 18,2956 & & & \\
\hline
\end{tabular}

Table 8.:The impact of exposure to the abundance of foliage galls

Tabela 8.: Uticaj izloženosti na prisustvo gala

\begin{tabular}{|c|c|c|c|c|c|}
\hline $\begin{array}{c}\text { Source: } \\
\text { Abundance of galls } \\
\text { on parts of crown }\end{array}$ & $\begin{array}{l}\text { Sum of } \\
\text { Squares }\end{array}$ & Df & $\begin{array}{c}\text { Mean } \\
\text { Square }\end{array}$ & F- Ratio & P- Value \\
\hline Between groups & 4637,22 & 3 & 1545,74 & 0,85 & 0,4686 \\
\hline Within groups & 1,153646 & 632 & 1825,38 & & \\
\hline Total & 1,158276 & 635 & & & \\
\hline
\end{tabular}

Table 9.: The significance of differences infestations main parts of the trees

Tabela 9.: Značajnost razlika zaraženosti glavnih dijelova krošanja

\begin{tabular}{|c|c|c|}
\hline Compared categories & Difference of means & Lower/upper limit \\
\hline East-South & 3,1888 & 9,21947 \\
\hline East-North & 2,42536 & 9,41699 \\
\hline East-West & 7,48581 & 9,35314 \\
\hline South-North & $-0,763447$ & 9,4443 \\
\hline South-West & 4,29701 & 9,38064 \\
\hline North-West & 5,06046 & 9,57484 \\
\hline
\end{tabular}

\section{DISCUSSION - Diskusija}

Lime avenue where the necessary observation was performed is located in an unfavorable habitat for its uninterrupted development. Because of daily influence of biotic factors, especially anthropogenic factor, the ground is very hard and degraded with crust on the surface or with sparse grass or ground vegetation. Simple habitat are more suitable for the mass occurrence of pests, and in more complex habitats rarely comes to mass occurrence of harmful insects (RAUP AND SHREWSBURY 2000, SHREWSBURY AND RAUP 2000). The emissions have inevitable impact on 
dislocation of linden trees to various pests. In recent years, the mites are given special attention and daily becoming more and more important group of organisms for research. Due to its extraordinary power of reproduction, mites in a short time can reach very high levels of population (SCHWENKE 1972).

Field and laboratory analysis revealed the presence of five species of planteating mites Eriophyes tiliae, Eriophyes tiliae lateannulatus, Eriophyes exilis, Eriophyes leiosoma and Eotetranychus tiliarum. Last species belongs to the family Tetranychidae and other to family Eriophyidae.

To determine the intensity of infection of linden trees by phytophagous mites HAWKSWORH'S six class system is used (1986). The advantage of this system is a relatively rapid assessment of intensity of infection, but the disadvantage is that the intensity is estimated only on the basis of certain indicators of the presence of mites, leading to neglect their number and age. Index 1 infection implies the presence of mites on to $50 \%$ of the branches in the analyzed part of the crown. This has the consequence that the same size of the index infection may reflect a different picture of the health status of affected individuals.

Trees that have been taken for analysis were grouped into three groups. Of the total number of analyzed trees on the 136 was identified the presence of phytophagous mites. According to the overall index of infestations largest number of infected trees is on site 1 dominated by trees with an index of infection 2 and 3 , on the site of 2 with an index of infection 3, while the third site are present trees with an index of 1 (Graphic 1). It should be noted that on the second and third site are most numerous trees with infestations index 0 . This arrangement of infested trees could be explained by the fact that the first location is represented by a lot of older trees, compared to other localities where there are a lot of mostly younger trees. When mites once appear on the tree, they do not leave him, but stay on it year after year and from there spread to neighboring trees. From this we can conclude that as the tree is longer located in one place, all the more likely to be attacked by phytophagous mites.

Display of infestations of trees on the analyzed parts of the canopy provides a better insight into the presence of phytophagous mites (Table 1). In the upper third of the crown are the most trees without the presence of mites (index 0 ), while the middle and lower third of the canopy is dominated by trees that have index 1 infection (Graphic 2). Also it is important to emphasize that there are twice as many number of trees in which the lower third of the canopy has an index of 2 infection compared to the mean. In the examined object proved to be certain regularity in terms of infection of some portion of the canopy. Moving from the bottom to the top of the canopy intensity of infection is reduced.

The conducted analysis has not established the existence of significant differences in the intensity of infection of linden treeswith phytophagous mites between locations (Table 2). The absence of these differences can be explained based on the areal ofa location which in this case is continuous, and based on environmental 
factors which are uniform throughout the entire area of research.The frequency of the eriophyoid mites inducing galls and the density of free living eriophyoid mites, especially of Aculusballei, varied considerably within lime species, irrespective of nursery location (SOIKA, 2006).

Analysis of the impact of the species of lime on intensity of infection with phytophagous mites did not show statistically significant (Table 3).

Analysis of variance of the analyzed parts of the tree crowns on the basis of the number of infected leaves and the number of galls has been established that there are no statistically significant differences in infection between the main parts of the crown (Table 5 and 8). The biggest differences are found between the eastern and western parts of the trees (Table 6 and 9 ).

\section{CONCLUSIONS- Zaključci}

In recent years, urban greenery is increasingly predisposed to attacks of phytophagous mites. The analysis revealed the presence of five species of phytophagous mites on the linden trees: Eriophyestiliae, Eriophyestiliaelateannulatus, Eriophyesexilis, Eriophyesleiosoma and Eotetranychustiliarum. On the object of the research 200 linden trees were analyzed, of which 136 received the title of infected trees. The presence of the latter type of mite is of great importance because it causes considerable damage on the important physiological health of the plants and it is considered the most important pest in the linden trees. Other species are of less importance. They are not physiological pests, but more aesthetic appearance of trees that loses role in urban environments.

The intensity of the attack was most pronounced in the lower third of the crown and declines extending from the lower to the higher parts of the canopy. At the site 1 are present older trees which are also trees with the largest index of infection, while on the remaining two sites the largest numbers of trees are not infected. 


\section{REFERENCES -Literatura}

BUTIN, H., NIENHAUS, F., BÖHMER, B. (2008): Atlas bolesti i štetnika na drveću i grmlju, ITD Gaudeamus

ČOMIĆ, R., ŠUMATIĆ, N., ČOMIĆ, D., GUDURIĆ, I., STANKOV, J. (2009): Zaštita urbanih šuma i zelenih površina, Akademsko udruženje "Eko logic", Banja Luka, Bosna i Hercegovina

HARTMANN, G., NIENHAUS, F., BUTIN, H. (2007): Atlas šumskih oštećenja Dijagnoze bolesti drveća, ITD Gaudeamus

LJUJIĆ-MIJATOVIĆ, T., MRDOVIĆ, A. (1998): Proizvodnja cvijeća i ukrasnog bilja, Studentska štamparija Univerziteta u Sarajevu.

MACELJSKI, M., IGRC-BARČIĆ,J., IVEZIĆ,M., MAČEK,J. (2002): Poljoprivredna entomologija, Zrinski

MATOŠEVIĆ, D. (2004): Fitofagne grinje drvenastih biljnih vrsta urbanog zelenila Zagreba, Šumarski institut 39 (2): 185-196, Jastrebarsko

PETANOVIĆ, R. (2004): Štetne grinje ukrasnih biljaka, Beografik, Beograd

PETANOVIĆ, R., MARČIĆ, D., VIDOVIĆ, B. (2010): Štetne grinje gajenih biljakaaktuelni problem, inovativni pristupi proučavanju i mogućnosti suzbijanja (1), Univerzitet u Beogradu, Poljoprivredni fakultet, Nemanjina 6, 11080 Beograd, Srbija

SCHNEIDER, K., H. BALDER, B. JÄCKEL, B. PRADEL, B. (2000): Bionomics of Eotetranichum tiliarum as influenced by key factors. Mitteilungenaus der Biologischen Bundesanstaltfür Land- und Forstwirtschaft. Int. Symp. Plant Health in Urban Horticulture, Braunschweig

SHREWSBURY, P., RAUPP, M. J. (2000): Crating landscapes that suppress insect pest outbreaks. Mitteilungenaus der Biologischen Bundesanstaltfür Land- und Forstwirtschaft. Int. Symp. Plant Health in Urban Horticulture, Braunschweig

SCHWENKE, W., (1972): Die Forstschädlinge Europas. 1. Band, Paul Parey Verlag, Berlin und Hamburg

SOIKA, G., (2006): Eriophyoid mites (Acari: Eriophyoidea) occurring on lime trees in ornamental nurseries, Biological lett. 2006, (43/2):367373

ŠIMUNOVIĆ, I. (2007): Urbana ekonomika, Školska knjiga d.d. Zagreb, Masarykova 28.

TIŠMA, A., NINIĆ-TODOROVIĆ, J., OGNJANOV, V. (2010): Studija zelenih i rekreativnih površina u cilju izrade revizije generalnog plana Novog Sada, Poljoprivredni fakultet Univerziteta u Novom Sadu 


\section{SAŽETAK}

Urbane zelene površine u Sarajevu su od neizmjerne važnosti za cjelokupan izgled grada i kvalitet življenja u njemu. Posljednjih godina ustanovljen je pad broja površina pod vegetacijom. Glavni razlog gubitka i degradacije zelenih površina je antropogeni faktor koji svojim aktivnostima predisponira urbano zelenilo raznim drugim biotskim i abiotskim faktorima. Aerozagađenje, suša, visoka temperature, zagađenje zemljišta i vode spadaju u grupu abiotskih faktora koji sinergijom uzrokuju značajne fiziološke promjene biljnih vrsta. Pad fiziološke otpornosti uzrokuje izloženost biljaka biotskim faktorima gdje posebno mjesto pripada insektima, gljivama, a u novije vrijeme i grinjama.

U ovom radu istraživanje je vršeno sa ciljem utvrđivanja i identifikacije štetnih vrsta grinja na stablima lipe i određivanje intenziteta zaraženosti stabala. Stabla lipe su koncipirana kao drvored na području Sarajeva. Identifikacija ovih štetnika vršena je direktno na terenu na osnovu zapaženih simptoma na lisnom materijalu. U slučaju da determinacija nije mogla biti izvršena odmah na terenu, ista se provodila u laboratoriji Katedre za zaštitu šuma i urbanog zelenila, Šumarskog fakulteta u Sarajevu. Intenzitet zaraženosti stabala je određivan HAWKSWORH-ovim šestoklasnim sistemom (1986).

Analizirano je 200 stabala od kojih je na 136 potvrđena zaraženost fitofagnim grinjama. Identifikovano je 5 vrsta grinja. Ustanovljene vrste pripadale su porodici Eriophyidae i Tetranychidae. Iz prve porodice su identifikovane sljedeće vrste grinja: Eriophyes tiliae, Eriophyes tiliae lateannulatus, Eriophyes exilis, Eriophyes leiosoma. Iz druge porodice utvrđeno je prisustvo grinje Eotetranychus tiliarum.

HAWKSWORH-ovim šestoklasnim sistemom ustanovljeno je da fitofagne grinje najviše nastanjuju donju trećinu krošnje. Njihova brojnost opada idući od nižih prema višim dijelovima krošnje Istraživanje je provođeno tokom maja, juna, jula i avgusta 2015. godine. 